\title{
Determinants of innovation and its impact on financial performance in South African family and non-family small and medium-sized enterprises
}

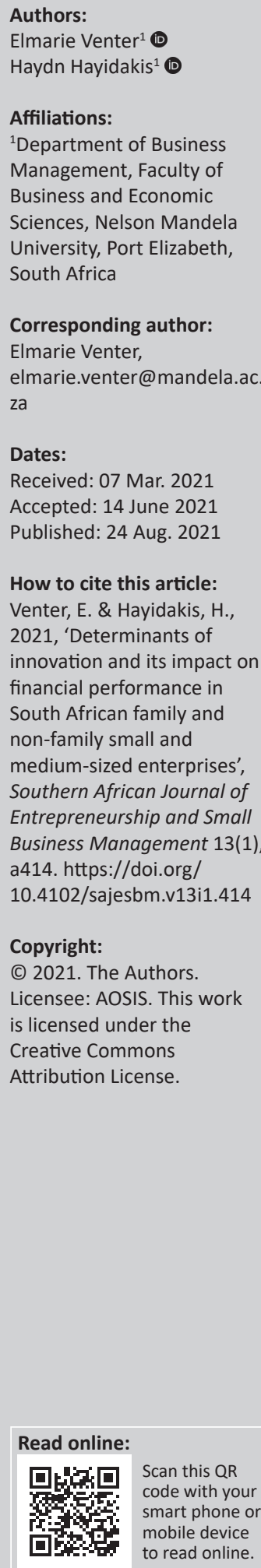

Background: The importance of innovation for enterprises of all sizes is well documented. However, existing research is ambiguous, with several research gaps concerning the role and nature of innovation in the performance of family and non-family small and medium-sized enterprises (SMEs), particularly in a South African context.

Aim: The aim of the study was to identify the determinants of innovation output, the types of innovation that are commonly being utilised and the influence thereof on perceived financial performance.

Setting: A total of 224 responses from family and non-family SMEs in South Africa were analysed in the study.

Methods: The statistical analysis included assessing the validity and reliability of the measuring instrument by using an exploratory factor analysis and Cronbach's alpha coefficients, respectively. Inferential statistics included calculating the Pearson's product moment correlations, a $t$-test, analysis of variance tests and multiple regression analyses.

Results: Predictors or determinants of Innovation output amongst family and non-family SMEs in this study are Innovation-orientated organisational culture, Market orientation and response and Risk-orientated entrepreneurial orientation. A significant and positive relationship was also found between Innovation output (which included product, process, organisational and marketing innovation) and Perceived financial performance. No differences were found concerning the innovation practices of family and non-family SMEs in this study.

Conclusion: Innovation plays an important role in improving the financial performance of SMEs. In addition, financial and human resources are not necessarily the main determinants of innovation in South African SMEs, but rather the creation of an innovation- and marketorientated organisational culture, together with a risk-orientated entrepreneurial orientation.

Keywords: small and medium-sized enterprises; family enterprises; innovation; innovation output; financial performance.

\section{Introduction, problem statement and the purpose of the study}

It is well known that small and medium-sized enterprises (SMEs) make critical economic and social contributions to most national economies (Amoah \& Amoah 2018). What is lesser well known is that most SMEs are also family-owned and controlled and play a significant role in global (Miroshnychenko et al. 2021) and African economies, including South Africa (Murphy \& Lambrechts 2015). In this study, an SME is defined as a enterprise that employs between 5 and 250 full-time employees and has been in operation for at least 2 years. Family SMEs are therefore defined by combining the definitions of family enterprises and SMEs, thus referring to a enterprise in which two or more family members work, or where a single family owns more than $50 \%$ of the enterprise and are active in its day-to-day activities, so long as it has been in operation for at least 2 years and employs between 5 and 250 employees.

Previous research revealed a positive relationship between innovation, enterprise performance and long-term value creation (Moses et al. 2011). In addition, innovation has been identified as a key driver of long-term economic growth and as the initiator of competitive strategy in the market (Moses et al. 2011). Considering South Africa's high (official) unemployment rate, it has become critical for all South African enterprises, including SMEs, to engage in innovative 
enterprise practices (Rogerson 2018). Not only will this allow SMEs to improve their chances of survival, but will also contribute towards the reduction of unemployment, inequality and poverty in South Africa (Hauck \& Prügl 2015; Rogerson 2018). Moreover, whilst crucial for all SMEs, innovation is of unique importance to family enterprises, as they rely on it to enhance their generational transition process and maintain the family's wealth over generations (Kellermanns et al. 2012). Innovation in this study refers to the introduction of a new or greatly enhanced product, service, process, marketing technique or organisational method incorporated into the internal structure and practices of a particular enterprise. These new products, services, processes or enterprise methods do not need to be entirely new to the market, industry or a country as a whole, but can rather just be novel to a particular enterprise (Lodh, Nandy \& Chen 2014).

De Massis et al. (2016) suggest that the lack of innovation strategies utilised by both family and non-family SMEs contributes to their high failure rates. Family enterprises in particular are often, but not always, considered less innovative than their non-family counterparts, which may influence their poor succession rates (Kellermanns et al. 2012). Furthermore, research gaps can be identified in the literature pertaining to innovation in both family and nonfamily SMEs, leaving our holistic knowledge of the topic incomplete (Hauck \& Prügl 2015). In addition, few observations have been made regarding the determinants of innovation in SMEs operating in developing countries, particularly in Africa (Jegede et al. 2012).

Given the gaps and ambiguity in existing literature regarding the role of innovation in the performance of family and nonfamily SMEs, coupled with the high failure rate of SMEs negatively affecting the South African economy, the purpose of this study was to investigate the nature of innovation in family and non-family SMEs, by identifying the factors that influence innovation output, the types of innovation that are commonly being utilised and the influence thereof on the perceived financial performance of South African family and non-family SMEs.

\section{Literature overview}

\section{Innovation, innovation output and perceived financial performance}

In this study, Innovation output includes the four types of innovation, namely product, process, organisational and marketing innovation. Product innovation refers to the creation and introduction of entirely new products and services into the market, or it can involve drastic improvements to existing products and services (Gunday et al. 2011; Moses et al. 2011). Process innovation involves the implementation of a drastically improved method of delivery or production occurring in a enterprise's methods, software and equipment that allows the enterprise to improve production or delivery times or reduce costs and wastage (Bozkurt \& Kalkan 2014; Gunday et al. 2011). Organisational innovation can be described as the implementation of a new or improved organisational method or behaviour in a enterprise's commercial practices, external relations or workplace organisation (Bozkurt \& Kalkan 2014). Marketing innovation is a method for enterprises to increase their sales by responding to the consumers' problems and needs in new and creative ways. This includes creating and implementing new or improved marketing campaigns, pricing strategies, product or service placements and promotional activities (Gunday et al. 2011).

Financial performance is considerably easier to measure than non-financial performance, as it is most commonly assessed by using monetary and economic indicators, such as profitability and growth (Gerba \& Viswanadham 2016:531-532). Despite advantages being found for using both financial and non-financial performance measures, many researchers have consistently only utilised financial indictors to measure the overall performance of a enterprise (Talib \& Shafie 2016:65). The reason for this may be because financial measures create a solid foundation from which to draw conclusions regarding the overall performance and success of a enterprise, as all enterprises' strategies and efforts are often aimed at creating sustainable profits and growth (Lotz \& Van der Merwe 2014:190). As such, this study will make use of financial measures to determine the overall performance of the enterprise. When measuring financial performance, empirical studies usually make use of 'perceived' measures (Talib \& Shafie 2016:65). The reason for this is because the feedback received from the respondents (owners and/or managers of family and non-family SMEs) is based on their subjective perspective of their enterprise's growth and profitability, as opposed to using objective data and financial records that are shared in the public domain (Soininen et al. 2012:616; Talib \& Shafie 2016:65). Therefore, for the purpose of this study, Perceived financial performance refers to the owner and/or manager's perception that the enterprise has been financially successful and achieved its financial goals by experiencing growth in profits, sales and the number of employees over the past 2 years.

\section{Independent variables: Determinants of innovation}

In this section, the relationships that exist between the proposed independent variables (Financial resources, Human resources and leadership, Information and knowledge, Entrepreneurial orientation [EO], Market orientation [MO] and Organisational culture [OC]) and Innovation output are discussed, together with anecdotal and empirical evidence for their inclusion in the hypothesised model.

\section{Financial resources}

Financial resources involve the monetary capital and available funds that are acquired through the owner(s) and their family, financial institutions, extended enterprise networks or the enterprise's own profitability (White, Maru \& Boit 2015). Having access to adequate internal financial resources can, however, be a challenge for SMEs, as they 
often have to turn to external financiers or risk operating without innovation, which could impede their development and leave them trailing behind their competitors (Hottenrott, Hall \& Czarnitzki 2016). Some of these external financiers can include, amongst others, financial institutions, banks, government, peer-to-peer, crowdfunding and angel investors. Because of risk-averse behaviour and long-term focus, family enterprises may struggle to attain external financing because they avoid sharing equity with non-family stakeholders (De Massis, Frattini \& Lichtenthaler 2013; Nieto et al. 2015). Several empirical studies have found a positive relationship between financial resources and innovation in SMEs (e.g. Lopez-Fernandez, Serrano-Bedia \& Gómez-López 2015; Nieto et al. 2015). Hence, the following hypothesis is proposed:

$\mathbf{H}^{1}$ : There is a positive relationship between Financial resources and the Innovation output of family and non-family SMEs.

\section{Human resources and leadership}

The capabilities of employees and management within a enterprise are important factors that facilitate the successful implementation of innovation (Caten et al. 2019; Vieites \& Calvo 2011). When a enterprise's management is open to innovation and also allows employees to get involved in the decision-making processes and innovation practices, the enterprise tends to exhibit greater innovation outputs (Nagy \& Băbăiță 2016). In addition to the management of the enterprise, leaders play a crucial role in creating an environment for innovations and sustainable development within a enterprise and will significantly affect the innovation process (Röd 2016). In family enterprises, family influence, or 'familiness', is a key determinant of innovation. Family members have an influence on the decision-making processes within the enterprise and subsequently influence the innovativeness of the enterprise either positively or negatively, depending on the family in question (Gast et al. 2018; Röd 2016). Thus, the following hypothesis is proposed:

$\mathbf{H}^{2}$ : There is a positive relationship between Human resources and leadership and the Innovation output of family and nonfamily SMEs.

\section{Information and knowledge}

Acquiring reliable information and knowledge, from internal and external sources, is important for SMEs to identify opportunities in the market and exploit them with relevant innovations (Jegede et al. 2012). SMEs, however, often struggle to generate their own internal information in comparison with large enterprises, as they do not possess the same capacity and resources to notice and effectively process knowledge and information. Despite this challenge, Jegede et al. (2012) suggest that networking and collaboration with other external enterprises and research entities are ways to overcome this capability shortfall. Collaborating with external entities is an important component of open innovation, as information and knowledge can be acquired through various external entities, such as customers, suppliers, competitors, allies, the Internet, social media platforms, the media, consultants, scientific research organisations, academic institutions, amongst others (El Samra et al. 2019). Family enterprises often form strong relationships inside and outside of the enterprise, which create an environment of free and easy communication and information exchanges (De Massis et al. 2013). The aforementioned anecdotal evidence is supported by empirical studies that found a positive relationship between information and knowledge and innovation in both family and non-family SMEs (e.g. El Samra et al. 2019; Jegede et al. 2012). As a result, the following hypothesis is formulated:

$\mathbf{H}^{3}$ : There is a positive relationship between Information and knowledge and the Innovation output of family and nonfamily SMEs.

\section{Entrepreneurial orientation}

In order for an innovation to be truly successful, it almost certainly requires elements of risk, proactiveness and a willingness to establish newness; thus, establishing a clear link between EO and innovation (Covin \& Wales 2018). In this study, EO is investigated as a multi-dimensional construct (Dele-Ijagbulu, Eresia-Eke \& Moos 2020) and includes three dimensions of EO, namely innovativeness, proactiveness and risk-taking. Innovativeness refers to a enterprise's willingness and capacity to engage in innovation activities (Gunawan, Jacob \& Duysters 2016). The proactive element of EO focusses primarily on the readiness of enterprises to seek and engage in innovation, as well as the timing of said innovation in relation to market conditions (Covin \& Wales 2018; Nasution et al. 2011). Risk-taking, on the other contrary, is the willingness to commit resources to projects with unknown outcomes (Hernández-Linares et al. 2020). Empirical research by Mohammed et al. (2020) and Nasution et al. (2011) revealed a positive correlation between EO and innovation. Based on this evidence, the following hypothesis is proposed:

$\mathbf{H}^{4}$ : There is a positive relationship between $E O$ and the Innovation output of family and non-family SMEs.

\section{Market orientation}

Dibrell, Craig and Hansen (2011) describe MO as a process whereby a enterprise achieves an understanding of the needs and expectations of customers whilst closely monitoring the activities of their competitors. MO is a concept, which is found to be a key determinant of innovation in enterprises (Voigt, Baccarella \& Wassmus 2011). Studies conducted by Riswanto et al. (2020) and Ho et al. (2018) found that MO did in fact have a positive influence on the financial performance of enterprises. A recent study conducted by Chipunza (2020) in South Africa and Zimbabwe found that both constructs of $\mathrm{MO}$ (customer orientation and competitor orientation) had a positive influence on all four types of innovation (product, process, organisational and marketing innovation). Beck et al. (2011) also confirmed the existence of a positive relationship between $\mathrm{MO}$ and innovation. Against this background, the following hypothesis is proposed: 
$\mathbf{H}^{5}$ : There is a positive relationship between $M O$ and the Innovation output of family and non-family SMEs.

\section{Organisational culture}

Whilst resources and capabilities are often the focus of research on innovation determinants (Vieites \& Calvo 2011), the OC within the enterprise has been strongly linked with innovation (Halim, Ahmad \& Ramayah 2019). Instilling an innovative OC in SMEs provides them with the ability to react in ways that will secure their competitive position, enhance creativity and achieve desired results in a turbulent market (Halim et al. 2015). In the context of family enterprises, OC is of particular importance, given that the values displayed within the family enterprise are usually based on the values of the founding family and are maintained throughout the enterprise's existence (Franco \& Lucas 2016). Previous empirical researches have established a positive relationship between OC and innovation (e.g. Ali Taha, Sirkova \& Ferencova 2016; Çakar \& Ertürk 2010; Halim et al. 2019; Uzkurt et al. 2013). Laforet (2016) states that little research exists that specifically examines the influence of OC on innovation in family enterprises. Against this background, the following hypothesis is formulated:

$\mathbf{H}^{6}$ : There is a positive relationship between $O C$ and the Innovation output of family and non-family SMEs.

\section{Innovation output and perceived financial performance}

Donkor et al. (2018), in their study amongst SMEs in Ghana, find that the higher an SME's innovative capacity, the more innovation outputs it produces and the better its financial performance tends to be. In a similar manner, Centobelli, Cerchione and Singh (2019) state that the more innovative SMEs are, the better their financial performance tends to be, as a result of the positive relationship that exists between these two variables. Bozkurt and Kalkan (2014), in a study amongst Turkish SMEs, find that SMEs mainly utilise two specific types of innovation, namely process and marketing innovation. Centobelli et al. (2019) find that higher levels of process innovation in manufacturing SMEs increase product innovation outputs, which further enhance financial performance. Similarly, Expósito and Sanchis-Llopis (2019) in their study find that product innovation has a positive influence on the sales and overall financial performance of SMEs. It is important to note that in a study conducted by Paula and Silva (2018) amongst 2745 European manufacturing enterprises, it was found that some innovation outputs had minimal influence on financial performance in the short term, but rather it took some time to emerge. Therefore, the following relationship is hypothesised:

$\mathbf{H}^{7}$ : There is a positive relationship between Innovation outputs and the Perceived financial performance of family and nonfamily SMEs.

\section{Innovative differences between family and non-family SMEs}

Several studies (e.g. Fredyna, Ruíz-Palomo \& Dieguez 2019; Jiménez-Jiménez, Sanz-Valle \& Perez-Caballero 2020; Kraus,
Pohjola \& Koponen 2012; Matzler et al. 2015; Price, Stoica \& Boncella 2013) have found innovation differences between family and non-family SMEs. A study conducted by Classen et al. (2014) have found that family enterprises invest less intensively than their non-family counterparts, whilst also tending to operate primarily in less innovation-intensive industries. To investigate whether there are perceived differences between family and non-family SMEs concerning the variables proposed in this study, the following null hypotheses were formulated:

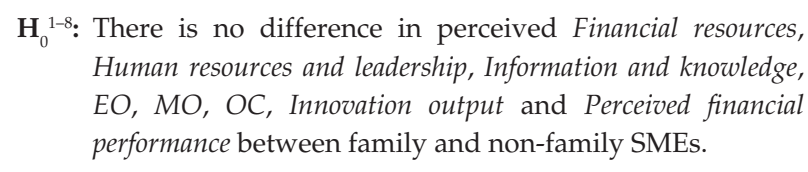

\section{Research design and methodology}

A positivistic research paradigm and deductive methodological approach was utilised in this study. Owing to the nature of this study, an online survey strategy was adopted, which used a closed-ended, structured and self-administered questionnaire to gather primary data for the purpose of this study.

\section{Measuring instrument design and administration}

The questionnaire consisted of two sections. Section A focussed on acquiring the demographic information of the respondents and their enterprises by means of multiplechoice questions. Section B made use of a seven-point Likert scale in which the respondents are able to indicate their level of agreement with statements measuring the independent variables (Financial resources, Human resources and leadership, Information and knowledge, EO, MO and OC) and the dependent variables (Innovation output and Perceived financial performance) of the study. In total, 54 randomised statements sourced from previous studies (see Table 1) were posed, which formed the basis for each variable's operationalisation. A complete list of the items is shown in Appendix 1.

Possible respondents were identified by using the sample frame generated for the purpose of this study and selected by using the non-probability sampling technique of convenience and snowball sampling. Once selected, family and nonfamily SMEs that agreed to participate were able to access the online questionnaire by using the link provided in the email or cover letter. No hard copy questionnaires were used in this study. To obtain ethical clearance, various ethical considerations were taken into consideration when creating and administering the measuring instrument. A formal ethics number was assigned by the relevant Ethics Committee before the empirical investigation commenced.

\section{Empirical results Response rate and demographic information}

Of the 4575 emails sent, a total of 224 (144 family SMEs and 80 non-family SMEs) responses were useable in the statistical analysis. The majority of the respondents who participated in this study were male $(71.9 \%)$, with female respondents consisting of only $28.1 \%$ of the total sample. The majority of 
TABLE 1: Operationalisation of variables, scale items and sources.

\begin{tabular}{|c|c|c|c|}
\hline Variable & Operationalisation & Number of items & Sources \\
\hline Perceived financial performance & $\begin{array}{l}\text { Perceived financial performance refers to the owner and/or } \\
\text { manager's perception that the enterprise has been financially } \\
\text { successful and achieved its financial goals by experiencing growth in } \\
\text { profits, sales and the number of employees over the past } 2 \text { years. }\end{array}$ & 6 & $\begin{array}{l}\text { Farrington (2009); Matchaba-Hove } \\
\text { (2013) }\end{array}$ \\
\hline Innovation output & $\begin{array}{l}\text { Refers to the enterprise providing customers with products and/or } \\
\text { services that offer unique benefits or changes (e.g. appearance and } \\
\text { packaging) that are superior to its competitors, as well as } \\
\text { consistently improving on its enterprise processes, equipment and } \\
\text { information-sharing practices, whilst regularly renewing its } \\
\text { marketing practices and after-sales services to customers. }\end{array}$ & 13 & Calik, Calisir and Cetinguc (2017) \\
\hline Financial resources & $\begin{array}{l}\text { The availability of and access to internal and external funding } \\
\text { sources that will enable the enterprise to fund changes or new } \\
\text { developments in its products, services, processes or enterprise } \\
\text { practices. }\end{array}$ & 5 & $\begin{array}{l}\text { Oliveira and Roth (2012) } \\
\text { Fleuren et al. (2014) }\end{array}$ \\
\hline Human resources and leadership & $\begin{array}{l}\text { Refers to the owners, managers and employees of the enterprise } \\
\text { having sufficient knowledge, experience, qualifications, experience, } \\
\text { skills, training and positive attitudes to identify and implement new } \\
\text { enterprise opportunities. }\end{array}$ & 5 & $\begin{array}{l}\text { Oliveira and Roth (2012); } \\
\text { Rahman and Kavida (2019) }\end{array}$ \\
\hline Information and knowledge & $\begin{array}{l}\text { Refers to a enterprise's access to relevant internal and external } \\
\text { information through social media, smartphones and instant } \\
\text { messaging. It also refers to the enterprise networking with external } \\
\text { entities in addition to the internal research activities conducted by } \\
\text { the enterprise that can be used to provide market insights and keep } \\
\text { up to date with changing trends and economic conditions to identify } \\
\text { opportunities and have the necessary knowledge to capitalise on } \\
\text { these opportunities. }\end{array}$ & 6 & $\begin{array}{l}\text { Ferris et al. (2005); Flores et al. } \\
\text { (2012). }\end{array}$ \\
\hline Entrepreneurial orientation & $\begin{array}{l}\text { Refers to the enterprise having the ability, capacity and willingness } \\
\text { to identify new enterprise opportunities, engage in innovation } \\
\text { activities, commit a large portion of its resources to risky ventures } \\
\text { and invest heavily in entrepreneurial product and/or market } \\
\text { initiatives. The enterprise also acts proactively to initiate actions to } \\
\text { which its competitors respond. }\end{array}$ & 5 & $\begin{array}{l}\text { Covin and Wales (2018); Fredyna } \\
\text { et al. (2019) }\end{array}$ \\
\hline Market orientation & $\begin{array}{l}\text { Refers to the enterprise demonstrating its commitment to its } \\
\text { customers by encouraging customer feedback, comments and } \\
\text { complaints, as well as monitoring customer satisfaction. In addition, } \\
\text { MO refers to the ability of the enterprise to identify current and } \\
\text { potential competitors' strengths, weaknesses and strategies. }\end{array}$ & 7 & Chipunza (2020) \\
\hline Organisational culture & $\begin{array}{l}\text { Refers to the enterprise creating a culture where employees are } \\
\text { actively encouraged, receive the required support to think and } \\
\text { behave in original and novel ways, take calculated risks with new } \\
\text { ideas, are allowed to try and solve problems in different and } \\
\text { creative ways, as well as where non-family employees are treated as } \\
\text { a part of the family in family enterprises. }\end{array}$ & 7 & $\begin{array}{l}\text { Calik et al. (2017); Price et al. (2013); } \\
\text { Riaz, Akhtar and Aslam (2018) }\end{array}$ \\
\hline
\end{tabular}

Source: Please see the full reference list of the article, Venter, E. \& Hayidakis, H., 2021, 'Determinants of innovation and its impact on financial performance in South African family and non-family small and medium-sized enterprises', Southern African Journal of Entrepreneurship and Small Business Management 13(1), a414. https://doi.org/10.4102/sajesbm.v13i1.414, for more information

respondents were between the ages of 50 to 59 years $(26.8 \%)$, followed by those between the ages of 40 to 49 years (21.9\%) and 20 to 29 years (18.8\%). Most of the respondents indicated that they were in possession of a tertiary qualification $(80.8 \%)$, whilst the remaining $19.2 \%$ were not. It is interesting to note that there is an almost even spread between the years (duration) that the enterprise has been in operation. Many of the enterprises have been operating for between 2 and 5 years (19.6\%), followed by those operating for longer than 30 years $(17.9 \%)$. Most of the enterprises in the sample employed between 5 and 10 employees (39.3\%), followed by those that employed between 21 and 50 employees (21.9\%), then between 11 and 20 employees (17.9\%) and between 51 and 100 employees (12.1\%). Most of the respondents indicated that their enterprise operates in the service industry $(35.7 \%)$, followed by other $(21.9 \%)$, retail and/or wholesale $(15.2 \%)$ and manufacturing $(14.3 \%)$.

\section{Validity and reliability results}

The reliability of the scales measuring the independent and dependent variables was tested by using an exploratory factor analysis (EFA) (Cooper \& Schindler 2014). Only factor loadings of 0.4 or greater and that loaded onto one factor were considered acceptable. Factor loadings that did not meet these requirements were removed from the results and excluded from further statistical analysis (Hair et al. 2014).

\section{Independent variables: Determinants of innovation}

Before the EFA was performed on the independent variables (determinants of Innovation output), the suitability of the data was assessed by using the KMO-MSA and Bartlett's Test of Sphericity. The KMO-MSA value was 0.882 and Bartlett's Test of Sphericity was statistically significant $(p<0.001)$. Hence, the data were deemed suitable to perform the EFA analysis, as both of the required conditions were satisfied. The factor structure from the EFA performed on the independent variables is displayed in Table 2 .

As seen in Table 2, three factors were extracted from the original six by using Principal Axis Factoring with a minimum factor loading of 0.4 . Three new factors emerged, which were re-named, with new operationalisations formulated for each. The questions (items) that constitute each factor structure were reviewed and labelled. The first factor (Factor 1) extracted did not correspond with any of the existing theoretical dimensions. Rather, numerous items intended to measure five of the original independent variables loaded onto this factor. Three originally intended to measure $O C$, two items measuring $E O$, one item intended to measure $M O$, one item measuring Human resources and leadership and one item intended to measure Information and knowledge loaded onto this factor. Therefore, this factor 
TABLE 2: Factor structure of the independent variables.

\begin{tabular}{|c|c|c|c|}
\hline Items & Factor 1 & Factor 2 & Factor 3 \\
\hline INFO6 & $0.959 \dagger$ & -0.162 & -0.263 \\
\hline MO1 & $0.638 \dagger$ & 0.046 & -0.148 \\
\hline EO2 & $0.632 \dagger$ & 0.079 & -0.066 \\
\hline OC1 & $0.562 \dagger$ & -0.161 & 0.399 \\
\hline HR4 & $0.506 \dagger$ & 0.005 & 0.177 \\
\hline OC7 & $0.470 \dagger$ & -0.023 & -0.014 \\
\hline EO1 & $0.453 \dagger$ & 0.012 & 0.353 \\
\hline OC3 & $0.446 \dagger$ & -0.012 & 0.220 \\
\hline MO7 & -0.081 & $0.845 \dagger$ & 0.004 \\
\hline $\mathrm{MO} 2$ & 0.034 & $0.695 \dagger$ & 0.007 \\
\hline MO5 & 0.170 & $0.686 \dagger$ & -0.196 \\
\hline FR1 & -0.133 & $0.675 \dagger$ & -0.064 \\
\hline EO3 & 0.113 & $0.529 \dagger$ & 0.065 \\
\hline $\mathrm{MO3}$ & 0.254 & $0.475 \dagger$ & -0.085 \\
\hline FR4 & -0.240 & $0.466 \dagger$ & 0.444 \\
\hline MO4 & 0.388 & $0.459 \dagger$ & -0.282 \\
\hline EO5 & 0.021 & -0.232 & $0.793 \dagger$ \\
\hline EO4 & 0.018 & -0.298 & $0.697 \dagger$ \\
\hline OC2 & -0.008 & 0.186 & $0.579 \dagger$ \\
\hline FR3 & -0.257 & -0.024 & $0.549 \dagger$ \\
\hline INFO1 & 0.032 & 0.145 & $0.466 \dagger$ \\
\hline HR5 & 0.078 & 0.329 & $0.422 \dagger$ \\
\hline OC4 & 0.385 & 0.073 & 0.249 \\
\hline OC5 & 0.335 & 0.109 & 0.228 \\
\hline OC6 & 0.32 & 0.116 & -0.229 \\
\hline HR1 & 0.148 & 0.247 & 0.282 \\
\hline HR2 & 0.048 & 0.241 & 0.390 \\
\hline HR3 & -0.158 & 0.352 & 0.393 \\
\hline INFO2 & 0.157 & 0.142 & 0.341 \\
\hline INFO3 & 0.179 & 0.309 & 0.292 \\
\hline INFO4 & 0.269 & 0.026 & 0.325 \\
\hline INFO5 & 0.304 & 0.226 & 0.062 \\
\hline MO6 & 0.303 & 0.368 & -0.065 \\
\hline FR2 & -0.210 & 0.134 & 0.327 \\
\hline FR5 & -0.016 & 0.145 & 0.111 \\
\hline Expl.Var & 7.595 & 7.700 & 7.501 \\
\hline Prp.Totl & 0.283 & 0.047 & 0.042 \\
\hline
\end{tabular}

$\dagger$, values loaded together onto each factor.

has been named Innovation-orientated OC, which explains $28.25 \%$ of the variance in the data. Factor loadings ranging between 0.959 and 0.446 were reported for this factor, as well as a Cronbach's alpha coefficient of 0.824 . Thus, there is sufficient evidence that the scale measuring Innovationorientated $O C$ is valid and reliable. In this study, Innovationorientated $O C$ refers to the enterprise having an innovationdriven internal OC where employees are treated as part of the family and are encouraged to actively think and behave in original ways to generate creative and innovative solutions to problems, whilst using market information and customer feedback to identify new enterprise opportunities.

Similar to the first factor, the second factor (Factor 2) extracted also did not correspond with any of the existing theoretical dimensions. Of the eight items that loaded onto this factor, five items were originally intended to measure $M O$, two items Financial resources and one item intended to measure $E O$. This factor has subsequently been named MO and response, which explains $4.65 \%$ of the variance in the data, with factor loadings ranging between 0.845 and 0.459 , confirming the validity of this scale. A Cronbach's alpha coefficient of 0.830 is reported, providing evidence of reliability. MO and response refers to the enterprise monitoring customer and competitor behaviour to quickly detect market threats and changes, whilst generating and allocating sufficient financial resources to develop new products, services or processes in response.

As with Factor 1 and Factor 2, the extraction of Factor 3 also did not correspond with any of the existing theoretical dimensions. Two items intended to measure $E O$, one item Financial resources, one item $O C$ and one item intended to measure Information and knowledge loaded onto this factor. Based on the nature of these items that loaded together, the new factor that emerged was named Risk-orientated $E O$, which accounts for $4.19 \%$ of the variance in the data. Factor loadings ranging between 0.763 and 0.480 were reported for the items measuring this factor, providing sufficient evidence of the scale's validity. A Cronbach's alpha coefficient of 0.735 was calculated, meaning that this scale can be considered reliable. In this study, Risk-orientated EO refers to the willingness of the enterprise to commit to and invest in risky entrepreneurial and market initiatives with uncertain outcomes so as to achieve enterprise growth. This implies that the enterprise is prepared to alter its products, services or processes, with these alterations being conducted by experienced employees, funded by friends and communicated by using social media.

\section{Dependent variable: Innovation output}

All 13 of the items intended to measure Innovation output loaded together onto one factor, as anticipated. Factor loadings ranging from 0.754 to 0.498 were extracted for the items that loaded onto this factor, providing sufficient evidence of validity. In addition, a Cronbach's alpha coefficient of 0.885 was reported, indicating that this scale is highly reliable. Finally, the construct of Innovation output explains $38.73 \%$ of the variance of the data. It is important to note that according to the results of the EFA, all of the items intended to measure Innovation output loaded together. This means that the items measuring each of the four types of innovation (product, process, organisational and marketing innovation) were all found to measure Innovation output. Based on the results of the EFA, the operationalisation of Innovation output remains unchanged from its original depiction.

\section{Dependent variable: Perceived financial performance}

As was the case with Innovation output, an individual EFA was performed together with the calculation of Cronbach's alpha coefficient to ensure that the scale measuring the dependent variable is valid and reliable. Each of the seven items that were intended to measure Perceived financial performance loaded together and provided evidence of validity by returning factor loadings ranging between 0.842 and 0.474 . Therefore, Perceived financial performance remained the name of this factor, which serves as a dependent variable in this study and explains $53.55 \%$ of the variance in the data. Moreover, the reliability of the scale was ensured, as a Cronbach's alpha coefficient of 0.874 was calculated. 


\section{Revised hypothesised model and hypotheses}

The results of the factor analyses that were performed required the formulation of new applicable names and operationalisations for the independent variables. Therefore, the null hypotheses have also been reformulated in line with the revised hypothesised model $\left(\mathrm{H}_{0}^{1-5}\right)$. However, the dependent variables (Innovation output and Perceived financial performance) remain unchanged. The revised hypothesised model is illustrated in Figure 1.

\section{Descriptive statistics}

The descriptive statistics of the data in this study showed that Innovation output returned a mean score of 4.10, whilst Perceived financial performance returned a mean score of 3.93 , with the majority of respondents agreeing with the items measuring these variables. Of the independent variables, Innovation-orientated $O C$ and $M O$ and response returned the highest mean scores of 4.42 and 4.24, respectively, with most respondents in agreement with the items measuring these variables. Alternatively, Riskorientated EO returned a neutral mean score of 3.22, with most respondents remaining neutral regarding the items measuring this variable.

\section{Inferential statistics}

The inferential statistics undertaken in this study include the calculation of Pearson's product moment correlations, a $t$-test, analysis of variance (ANOVA) tests and multiple regression analyses (MRAs). The results of these statistical procedures will now be discussed in the sections to follow.

\section{Pearson's product moment correlations}

Pearson's product moment correlation coefficients were calculated and used to determine whether any association or correlation exists between the independent variables (Innovation-orientated OC, MO and response and Riskorientated EO), Innovation output and Perceived financial performance. Significant positive correlations were reported between all three of the independent variables, whilst each of the independent variables also reported strong positive relationships with Innovation output. Two of the independent variables, $\mathrm{MO}$ and response and Risk-orientated $E O$, were found to have significant positive relationships with Perceived financial performance, whilst the relationship between Innovation-orientated $O C$ and Perceived financial performance was weak. Finally, a strong positive correlation was found between Innovation output and Perceived financial performance.

\section{Results of the $t$-test: Family versus non-family small and medium-sized enterprises}

A two-tailed independent sample $t$-test was conducted to determine whether there was a significant difference in the perception of family and non-family SMEs concerning the three independent variables (Innovation-orientated OC, MO and response and Risk-orientated EO) and the dependent variables (Innovation output and Perceived financial performance). No significant $(p>0.05)$ differences in the perceptions between family and non-family SMEs were found concerning the five variables, which is illustrated in Figure 1, after the factor analysis was conducted. In other words, there is no difference in the perception of family and non-family SMEs regarding the mean scores of Innovationorientated $O C, M O$ and response, Risk-orientated EO, Innovation output and Perceived financial performance. As such, $\mathrm{H}_{0}{ }^{1}, \mathrm{H}_{0}{ }^{2}$, $\mathrm{H}_{0}{ }^{3}, \mathrm{H}_{0}{ }^{4}$ and $\mathrm{H}_{0}{ }^{5}$ are not rejected.

\section{Hypotheses testing}

The first analysis was conducted to determine whether significant positive relationships exist between the independent variables (determinants of innovation), namely Innovation-orientated OC, MO and response and Risk-orientated $E O$, and the dependent variable, Innovation output. The second MRA was performed with Innovation output as the independent variable and Perceived financial performance as the dependent variable. In both cases, control variables were introduced based on the significant differences of scores identified in the ANOVA tests. These control variables are Enterprise size, Enterprise age and Industry. Prior to the commencement of the two MRAs, several tests were performed (e.g. variance inflation factors and residual

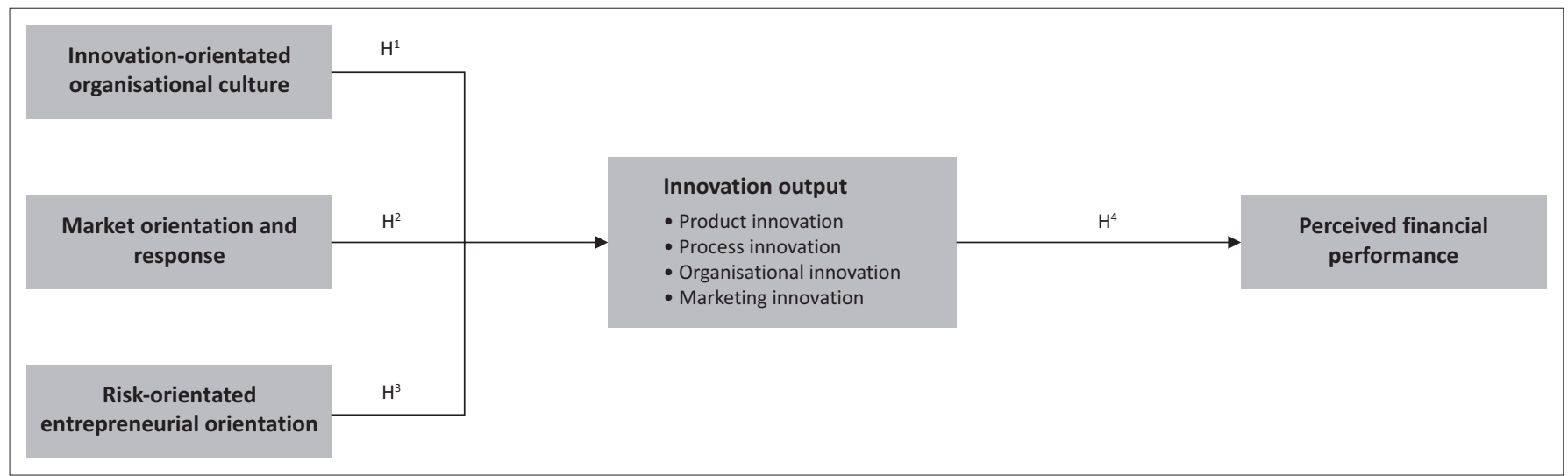

FIGURE 1: Revised hypothesised model: Determinants of Innovation output and its influence on Perceived financial performance. 
analysis) to satisfy the necessary assumptions, with the results confirming that these assumptions were all adequately met.

\section{Results of the multiple regression analyses: Independent variables and innovation output}

Given that the global F-test's $p$-value was significant $(p<0.001)$, at a $5 \%$ level of significance, the model was considered adequate for prediction purposes. With an $R^{2}$ value of 0.800 , the results of the MRAs show that the control variables and the independent variables explain $80 \%$ of the variance in Innovation output (Table 3).

Table 3 presents the results of the first MRA analysing the relationships between the independent variables and Innovation output. The first MRA reported significant and positive relationships between all three independent variables (Innovation-orientated OC, MO and response and Riskorientated EO) and Innovation output. The beta coefficients reported for all of these relationships are greater than 0.20 , suggesting the presence of interpretable linear relationships (Lee 2014). Regarding the control variables, a significant positive relationship was reported between the control variable Enterprise age and the dependent variable Innovation output $(\beta=0.159 ; p<0.05)$.

There is a significant positive linear relationship $(\beta=0.218$; $p<0.05)$ between Innovation-orientated OC and Innovation output. However, the MRA suggested that Innovationorientated OC $(t$-value $=4.782)$ exerts the least influence of the independent variables on Innovation output, which corresponds with the results of Pearson's product moment correlations. The strongest significant positive linear relationship ( $\beta=0.534 ; p<0.05$ ) was reported between $M O$ and response and Innovation output. In addition, it was reported that $M O$ and response $(t$-value $=12.608)$ exerts the strongest influence on Innovation output. Finally, a significant positive linear relationship $(\beta=0.278 ; p<0.05)$ was also reported between Risk-orientated $E O$ and Innovation output. With a $t$-value of 7.844 , Risk-orientated $E O$ exerts slightly more influence than Innovation-orientated $O C$, but less influence than $M O$ and response, on Innovation output.

TABLE 3: Regression results: Independent variables and Innovation output.

\begin{tabular}{lccc}
\hline Independent variables & \multicolumn{3}{c}{ Dependent variable: Innovation output $\left(\boldsymbol{R}^{\mathbf{2}}=\mathbf{0 . 8 0 0}\right)$} \\
\cline { 2 - 4 } & Beta $(\boldsymbol{\beta})$ & $\boldsymbol{t}$-value & Significance $(\boldsymbol{p})$ \\
\hline Intercept & -0.137 & -0.775 & 0.439 \\
Enterprise size & -0.034 & -0.600 & 0.549 \\
Enterprise age 1 & 0.099 & 1.447 & 0.149 \\
Enterprise age 2 & 0.159 & 2.698 & 0.008 \\
Industry 1 & 0.054 & 0.789 & 0.431 \\
$\begin{array}{l}\text { Industry 2 } \\
\begin{array}{l}\text { Innovation-orientated } \\
\text { organisational culture }\end{array}\end{array}$ & 0.052 & 0.733 & 0.464 \\
$\begin{array}{l}\text { Market orientation and } \\
\text { response }\end{array}$ & 0.218 & 4.782 & 0.000 \\
$\begin{array}{l}\text { Risk-orientated } \\
\text { entrepreneurial orientation }\end{array}$ & 0.534 & 12.608 & 0.000 \\
\hline
\end{tabular}

Against this background, support is found for the hypothesised relationships between Innovation-orientated OC $\left(\mathrm{H}^{1}\right), M O$ and response $\left(\mathrm{H}^{2}\right)$ and Risk-orientated $E O\left(\mathrm{H}^{3}\right)$, and the dependent variable, Innovation output.

\section{Results of the multiple regression analyses: Innovation output and perceived financial performance}

Given that the global F-test's $p$-value was significant $(p<0.001)$, at a $5 \%$ level of significance, the model was considered adequate for prediction purposes. The results of the MRA (Table 4) show that the control variables and Innovation output explain $40.20 \%\left(R^{2}=0.402\right)$ of the variance in Perceived financial performance. For the control variables, a significant negative relationship was reported between the control variable Enterprise size and the dependent variable Perceived financial performance $(\beta=-0.328 ; p<0.05)$.

Table 4 presents the results of the second MRA analysing the relationship between Innovation output and Perceived financial performance. A significant positive linear relationship $(\beta=0.791 ; p<0.05)$ exists between Innovation output and Perceived financial performance. Again, the beta coefficient reported for this relationship is greater than 0.20 , suggesting the presence of an interpretable linear relationship (Lee 2014). This means that the more the Innovation output increases, the higher the Perceived financial performance of the enterprise. Therefore, support is found in this study for the hypothesised relationship $\left(\mathrm{H}^{4}\right)$ between Innovation output and Perceived financial performance.

\section{Discussion of results}

All of the SMEs in this study, family and non-family owned, considered innovation as an important activity in their enterprises. This result is in accordance with the findings of Price et al. (2013), who found that innovation was a significant factor in both family and non-family SMEs. In addition, Werner, Schroder and Chlosta (2018) also reported that family SMEs hold innovation as an important consideration in their enterprises.

Furthermore, no significant differences were found between the innovation practices of family and non-family SMEs in this study. These findings are in contrast with most other studies that did report the existence of innovative differences between family and non-family SMEs (Kraus et al. 2012). For example, Matzler et al. (2015) found that family enterprises

TABLE 4: Regression results: Innovation output and perceived financial performance. Independent variables Dependent variable: Perceived financial performance

\begin{tabular}{lccc} 
& \multicolumn{3}{c}{$\left(\boldsymbol{R}^{\mathbf{2}=\mathbf{0 . 4 0 2})}\right.$} \\
\cline { 2 - 4 } & $\boldsymbol{B e t a}(\boldsymbol{\beta})$ & $\boldsymbol{t}$-value & Significance $(\boldsymbol{p})$ \\
\hline Intercept & 0.869 & 2.974 & 0.003 \\
Enterprise size & -0.328 & -2.663 & 0.008 \\
Enterprise age 1 & -0.065 & -0.440 & 0.660 \\
Enterprise age 2 & -0.130 & -0.974 & 0.331 \\
Industry 1 & 0.233 & 1.523 & 0.129 \\
Industry 2 & -0.010 & -0.063 & 0.949 \\
Innovation output & 0.791 & 10.637 & 0.000 \\
\hline
\end{tabular}


produce greater innovation outputs than non-family enterprises, whilst Classen et al. (2014) revealed that when family SMEs have a higher propensity to invest in innovation, they do so less intensively than their non-family counterparts. However, there is some literary support for the results of the $t$-test in this study. When comparing thousands of Australian and Belgian family and non-family SMEs, Smith (2008) found that the proposed differences between family and non-family enterprises may be less significant than many earlier studies had indicated. The study also demonstrated that the underlying theoretical rationale for several predicted differences between family and non-family enterprises appeared to be flawed. Moreover, Werner et al. (2018), in their research amongst almost 2000 German SMEs, reported that family SMEs are just as innovative as their non-family counterparts.

The empirical results revealed a significant and positive relationship between the independent variable Innovationorientated OC and Innovation output. This result is supported by prior research (e.g. Ali Taha et al. 2016; Uzkurt et al. 2013). In addition, Halim et al. (2015) reported that SMEs with an OC that is focussed on innovation exhibit significantly higher innovation outputs than those that are not. Furthermore, the employee element of this variable whereby employees are treated as a part of the family and encouraged to actively think and behave in original ways is supported by Çakar and Ertürk (2010), who in their study found that when SMEs provide an OC that promotes employee creativity and freedom to pursue opportunities, the more innovative the enterprise tends to be. Therefore, the results of this study support $\mathrm{H}^{1}$.

The strongest significant positive relationship was reported between MO and response and Innovation output, which confirmed that $M O$ and response is a determinant of Innovation output. Consequently, $\mathrm{H}^{2}$ is accepted. This result is supported by the research of Riswanto et al. (2020) and Ho et al. (2018), who reported that the general concept of $\mathrm{MO}$ has a positive influence on, and promotes, innovation in enterprises operating in developing economies. Moreover, the study by Chipunza (2020) reiterated this support in a local setting, as it was reported that SMEs in South Africa and Zimbabwe benefit from higher innovation outputs as a result of exhibiting high levels of customer and competitor-focused MO. The same positive relationship was found by Beck et al. (2011) amongst family enterprises.

Finally, a significant positive relationship between Riskorientated $E O$ and Innovation output was also found, confirming the acceptance of $\mathrm{H}^{3}$. Whilst the general theme of EO was captured in this variable, the dimension of risk-taking was the most prominent feature. The study by Fernández-Mesa, Alegre-Vidal and Chiva-Gómez (2012) supports the findings of this study by reporting a significant positive relationship between EO and Innovation output. Furthermore, Nasution et al. (2011) added that a strong EO and a willingness to take risks when developing new products, services or processes in SMEs are highly correlated with innovation. Similarly,
Jiménez-Jiménez et al. (2020) reported a strong positive relationship between EO and innovation. Therefore, existing empirical research supports the findings of this study.

In this study, a significant and positive relationship was specifically found between Innovation output and Perceived financial performance, accepting $\mathrm{H}^{4}$. Therefore, as a enterprise increases its innovation outputs - the better it will perform in financial terms. This means that Innovation output has a direct influence on the enterprise's financial well-being by improving profits, increasing sales and increasing employee numbers. The findings of this study are supported by previous research (e.g. Ho et al. 2018; Vieites \& Calvo 2011), which found a significant positive correlation between innovation and financial performance.

\section{Managerial implications}

In the context of the Innovation-orientated OC and Innovation output, the owner(s) and/or manager(s) need to ensure that their enterprise creates and maintains an OC, which treats all employees as part of the 'family' and that is inclusive of all employees, whether they are family or non-family employees. Positive organisational outcomes such as commitment, productivity, adaptability and innovativeness result from the presence of an OC that promotes employees' sense of family and belonging in the enterprise. Family enterprises should make use of this as they already place a strong emphasis on building social binding ties and they are commonly more inclined to build strong social relationships inside and outside of the enterprise. In addition, employees should be encouraged to actively think and behave in original ways to generate creative and innovative solutions to problems, whether it involves the enterprise's products or services, processes, organisational structure and/or marketing practices. Management should provide employees with the freedom to try new things and think outside of the box without fear of serious repercussions, as long as their actions are ethical and responsible.

Concerning MO and response and Innovation output, the owners and/or management and/or leadership of SMEs should have systems and processes in place to assess customer and competitor behaviour to speedily detect market threats and changes. In other words, and in line with the previous finding, an OC should also be created that values the feedback and opinions of customers. In this way, new opportunities in the market could be identified, and existing products or services, processes, organisational and marketing activities could be improved according to the desires of the consumer market. Regular consultations must be conducted with customers to obtain feedback about whether the enterprise is doing well, and more importantly, what it can do to improve. Given their size and OC, SMEs and family enterprises, in particular, often have a closer and more personal connection with the market, which they could utilise in this regard. Existing and potential competitors must be monitored to identify gaps in their offering that could be filled by one's own enterprise; or reveal the competitors' 
innovations that may need to be counteracted to retain competitive advantage in the market. Furthermore, SMEs should consider adopting an 'open' approach to innovation. By adopting an 'open innovation' approach, SMEs will be able to use external sources of information and knowledge (e.g. universities, the Internet, other enterprises, research institutions and government publications) to supplement their own efforts and capabilities.

Regarding Risk-orientated EO and Innovation output, SMEs should 'invest' in skilled and trained employees if they want to partake in riskier entrepreneurial and innovative initiatives. Pursuing riskier, but more rewarding, innovation ventures or practices often requires experience, knowledge and expertise from employees to reduce risk, whilst also improving the venture's potential success. Financial institutions and traditional sources of financing are not always willing to lend money to small enterprises for the purpose of risky innovative ventures. Therefore, SMEs should consider using personal relations, such as friends, family and professional acquaintances, to acquire the necessary funds. Once again, SMEs could adopt an 'open' approach to innovation, whereby enterprises can collaborate with external entities and utilise external information sources to help reduce the risk of innovation ventures.

The results of this study confirmed that product, process, organisational and marketing innovation all constitute Innovation output and play an important role in improving the competitive advantage of the enterprise. Based on a significant positive relationship between Innovation output and Perceived financial performance in this study, it can be strongly recommended that enterprises seek to innovate in some capacity. This may be through product, process, organisational or marketing innovation, as these types of innovation have all been found to create a competitive advantage and enhance financial performance. Therefore, enterprises should aim to deliver the best and most unique product or service offering to best satisfy consumer needs.

\section{Limitations of the study and recommendations for future research}

In the literature review, it became clear that innovation is a complex and multi-dimensional concept and construct. As a result, a challenge, more than a limitation, was to identify the dependent variable in this study. Future research should take this into consideration when comparing the results of this study that used Innovation output as its main dependent variable, with other research findings.

Another limitation of this study is that it focussed on a selected number of internal determinants of innovation in SMEs. In particular, this study does not account for external determinants of innovation, such as environmental munificence, national and local governmental laws and regulations and available infrastructure. In the current study, the sample size and sampling techniques used may also be considered as limitations. The non-probability sampling techniques of convenience and snowball sampling used in this study are associated with various disadvantages, such as the potential presence of a sampling bias and the results being less representative of the study population, which limits the accuracy with which generalisations can be made about the research population (Mitchell \& Jolley 2010).

\section{Conclusion}

This study investigated the determinants of innovation output, the types of innovation that are commonly being utilised and the influence thereof on perceived financial performance. From the findings, it is evident that innovation plays an important role in increasing the financial performance of SMEs. In addition, financial and human resources are not necessarily the main determinants of innovation in South African SMEs, but rather the creation of an innovation and market-orientated OC, together with a risk-orientated EO. No differences were found concerning the innovation practices of family and non-family SMEs in this study.

\section{Acknowledgements}

The authors would like to thank all respondents who took part in the survey as well as the Office of Research Development at the Nelson Mandela University, South Africa.

\section{Competing interests}

The authors have declared that no competing interests exist.

\section{Authors' contributions}

Both authors contributed equally to the development of the manuscript. H.H. conducted the initial research as part of his master's dissertation under the supervisor of E.V.

\section{Ethical considerations}

Ethical approval for this study was obtained from the Faculty Ethics Committee of the Faculty of Enterprise and Economic Science (Nelson Mandela Metropolitan University), with ethical clearance number: H20-BES-BMA-037.

\section{Funding information}

This research received no specific grant from any funding agency in the public, commercial or not-for-profit sectors. Funding assistance was received from the Office of Research Development at the Nelson Mandela University, South Africa.

\section{Data availability}

The data that support the findings of this study are available from the corresponding author, E.V., upon reasonable request. 


\section{Disclaimer}

The views and opinions expressed in the article are those of the authors and do not necessarily reflect the official policy or position of any affiliated agency of the authors.

\section{References}

Ali Taha, V., Sirkova, M. \& Ferencova, M., 2016, 'The impact of organizational culture on creativity and innovation', Polish Journal of Management Studies 14(1), 7-17. https://doi.org/10.17512/pjms.2016.14.1.01

Amoah, S.K. \& Amoah, A.K., 2018, 'The role of small and medium enterprises (SMEs) to employment in Ghana', International Journal of Business and Economics Research 7(5), 151-157. https://doi.org/10.11648/j.ijber.20180705.14

Beck, L., Janssens, W., Debruyne, M. \& Lommelen, T., 2011, 'A study of the relationships between generation, market orientation, and innovation in family firms', Family Business Review 24(3), 252-272. https://doi.org/10.1177/0894486511409210

Bozkurt, O.C. \& Kalkan, A., 2014, 'Business strategies of SME's, innovation types and factors influencing their innovation: Burdur model', Ege Academic Review 14(2), 189-198. https://doi.org/10.1177/0894486511409210

Çakar, N.D. \& Ertürk, A., 2010, 'Comparing innovation capability of small and mediumsized enterprises: Examining the effects of organizational culture and empowerment', Journal of Small Business Management 48(3), 325-359. https:// doi.org/10.1111/j.1540-627X.2010.00297.x

Calik, E., Calisir, F. \& Cetinguc, B., 2017, 'A scale development for innovation capability measurement', Journal of Advanced Management Science 5(2), 69-76. https:// doi.org/10.18178/joams.5.2.69-76

Caten, C.S., Silva, D.S., Aguiar, R.B., Filho, L.C.P.S. \& Huerta, J.M.P., 2019, 'Reshaping engineering learning to promote innovative entrepreneurial behavior', Brazilian Journal of Operations \& Production Management 16(1), 141-148. https://doi. org/10.14488/BJOPM.2019.v16.n1.a13

Centobelli, P., Cerchione, R. \& Singh, R., 2019, 'The impact of leanness and innovativeness on environmental and financial performance: Insights from Indian SMEs', International Journal of Production Economics 212(1), 111-124. https:// doi.org/10.1016/j.ijpe.2019.02.011

Chipunza, L.T., 2020, 'Innovation in small accommodation businesses: A comparative study of Zimbabwe and South Africa', Acta Commercii 20(1), 1-10. https://doi. org/10.4102/ac.v20i1.796

Classen, N., Carree, M., Van Gils, A. \& Peters, B., 2014, 'Innovation in family and nonfamily SMEs: An exploratory analysis', Small Business Economics 42(3), 595-609. https://doi.org/10.1007/s11187-013-9490-z

Cooper, D.R. \& Schindler, P.S., 2014, Business research methods, 12th edn., McGrawHill, New York, NY

Covin, J.G. \& Wales, W.J., 2018, 'Crafting high-impact entrepreneurial orientation research: Some suggested guidelines', Entrepreneurship Theory and Practice research: Some suggested guidelines', Entrepreneurship

De Massis, A., Frattini, F. \& Lichtenthaler, U., 2013, 'Research on technological innovation in family firms: Present debates and future directions', Family Business Review 26(1), 10-31. https://doi.org/10.1177/0894486512466258

De Massis, A., Kotlar, J., Frattini, F., Chrisman, J.J. \& Nordqvist, M., 2016, 'Family governance at work: Organizing for new product development in family SMEs', Family Business Review 29(2), 189-213. https://doi.org/10.1177/ 0894486515622722

Dele-ljagbulu, O., Eresia-Eke, C. \& Moos, M., 2020, 'Dimensions of firm-level entrepreneurial orientation as antecedents to employment growth in SMMEs', African Journal of Business and Economic Research (AJBER) 15(3), 91-114. https:// doi.org/10.31920/1750-4562/2020/v15n3a4

Dibrell, C., Craig, J. \& Hansen, E., 2011, 'Natural environment, market orientation, and firm innovativeness: An organizational life cycle perspective', Journal of Small Business Management 49(3), 467-489. https://doi.org/10.1111/j.1540$627 X .2011 .00333 . x$

Donkor, J., Donkor, G.N.A., Kankam-Kwarteng, C. \& Aidoo, E., 2018, 'Innovative capability, strategic goals and financial performance of SMEs in Ghana', Asia Pacific Journal of Innovation and Entrepreneurship 12(2), 238-254. https://dol. org/10.1108/APJIE-10-2017-0033

El Samra, A., Anastasakis, L., Albores, P. \& Uren, V., 2019, 'Big data big impact: How firms are using social media for innovation and better performance', International Conference on Advances in Business Management and Law ICABML 2, 32-42. https://doi.org/10.30585/icabml-cp.v2i1.180

Expósito, A. \& Sanchis-Llopis, J.A., 2019, 'The relationship between types of innovation and SMEs' performance: A multi-dimensional empirical assessment', Eurasia Business Review 9(2), 115-135. https://doi.org/10.1007/s40821-018-00116-3

Farrington, S.M., 2009, 'Sibling partnerships in South African small and medium-sized family businesses', Unpublished Doctoral thesis, Nelson Mandela Metropolitan University.

Fernández-Mesa, A., Alegre-Vidal, J. \& Chiva-Gómez, R., 2012, 'Entrepreneurial orientation, organizational learning capacity and innovative performance', Journal of Technology Management and Innovation 7(2), 157-170. https://doi org/10.4067/S0718-27242012000200013

Ferris, G.R., Treadway, D.C., Kolodinsky, R.W., Hochwarter, W.A., Kacmar, C.J., Douglas, C. et al., 2005, 'Development and validation of the political skill inventory', Journ of Management 31(1), 126-152. https://doi.org/10.1177/0149206304271386
Fleuren, M.A.H., Paulussen, T.G.W.M., Van Dommelen, P. \& Van Buuren, S., 2014, Measurement instrument for determinants of innovations (MIDI), TNO, Leiden.

Flores, L.G., Zheng, W., Rau, D. \& Thomas, C.H., 2012, 'Organisational learning: Subprocess identification, construct validation, and an empirical test of cultural antecedents', Journal of Management 38(2), 640-667. https://doi. org/10.1177/0149206310384631

Franco, M. \& Lucas, M., 2016, 'Family management of SMEs: An organisational culture perspective', International Journal of Globalisation and Small Business 8(1) 18-38. https://doi.org/10.1504/IJGSB.2016.076442

Fredyna, T., Ruíz-Palomo, D. \& Dieguez, J., 2019, 'Entrepreneurial orientation and product innovation. The moderating role of family involvement in management' European Journal of Family Business 2019(9), 128-145. https://doi.org/10.24310/ ejfbejfb.v9i2.5392

Gast, J., Filser, M., Rigtering, J.C., Harms, R., Kraus, S. \& Chang, M.L., 2018, 'Socioemotional wealth and innovativeness in small and medium-sized family enterprises: A configuration approach', Journal of Small Business Management 56(1), 53-67. https://doi.org/10.1111/jsbm.12389

Gerba, Y.T. \& Viswanadham, P., 2016, 'Performance measurement of small-scale enterprises: Review of theoretical and empirical literature', International Journal of Applied Research 2(3), 531-535.

Gunawan, T., Jacob, J. \& Duysters, G., 2016, 'Network ties and entrepreneurial orientation: Innovative performance of SMEs in a developing country', International Entrepreneurship Management Journal 12(1), 575-599. https://doi. org/10.1007/s11365-014-0355-y

Gunday, G., Ulusoy, G., Kilic, K. \& Alpkan, L., 2011, 'Effects of innovation types on firm performance', International Journal of Production Economics 133(1), 662-676. https://doi.org/10.1016/j.ijpe.2011.05.014

Hair, J.F., Black, W.C., Babin, B.J. \& Anderson, R.E., 2014, Multivariate data analysis, 7th edn., Pearson, Hoboken, NJ.

Halim, H.A., Ahmad, N.H. \& Ramayah, T., 2019, 'Sustaining the innovation culture in SMEs: The importance of organisational culture, organisational learning and market orientation', Asian Journal of Business Research 9(2), 14-33. https://doi org/10.14707/ajbr.190059

Halim, H.A., Ahmad, N.H., Ramayah, T., Hanifah, H., Taghizadeh, S.K. \& Mohamad, M.N., 2015, 'Towards an innovation culture: Enhancing innovative performance of Malaysian SMEs', Academic Journal of Interdisciplinary Studies 4(2), 85-93.

Hauck, J. \& Prügl, R., 2015, 'Innovation activities during intra-family leadership succession in family firms: An empirical study from a socioemotional wealth perspective', Journal of Family Business Strategy 6(1), 104-118. https://doi. perspective', Journal of Family
org/10.1016/j.jfbs.2014.11.002

Hernández-Linares, R., Kellermanns, F.W., López-Fernández, M.C. \& Sarkar, S., 2020 'The effect of socio-emotional wealth on the relationship between entrepreneurial orientation and family enterprise performance', Enterprise Research Quarterly orientation and family enterprise performance', Enterprise Res
23(3), 174-192. https://doi.org/10.1177/2340944420941438

Ho, K.L.P., Nguyen, C.N., Adhikari, R., Miles, M.P. \& Bonney, L., 2018, ‘Exploring market orientation, innovation, and financial performance in agricultural value chains in emerging economies', Journal of Innovation \& Knowledge 3(3), 154-163. https:// doi.org/10.1016/j.jik.2017.03.008

Hottenrott, H., Hall, B.H. \& Czarnitzki, D., 2016, 'Patents as quality signals? The implications for financing constraints on R\&D', Economics of Innovation and New Technology 25(3), 197-217. https://doi.org/10.1080/10438599.2015.1076200

Jegede, O.O., Ilori, M.O., Sonibare, J.A., Oluwale, B.A. \& Siyanbola, W.O., 2012 'Factors influencing innovation and competitiveness in the service sector in Nigeria: A sub-sectoral approach', Management 2(3), 69-79. https://doi. org/10.5923/j.mm.20120203.03

Jiménez-Jiménez, D., Sanz-Valle, R. \& Perez-Caballero, J.A., 2020, 'Entrepreneurial orientation and innovation success in family firms', International Journal of Entrepreneurship and Small Business 40(1), 114-127. https://doi.org/10.1504/ IJESB.2020.106941

Kellermanns, F.W., Eddleston, K.A., Sarathy, R. \& Murphy, F., 2012, 'Innovativeness in family firms: A family influence perspective', Small Business Economics 38(1) 85-101. https://doi.org/10.1007/s11187-010-9268-5

Kraus, S., Pohjola, M. \& Koponen, A., 2012, 'Innovation in family firms: An empirical analysis linking organizational and managerial innovation to corporate success', Review of Managerial Science 6(3), 265-286. https://doi.org/10.1007/s11846011-0065-6

Laforet, S., 2016, 'Effects of organisational culture on organisational innovation performance in family firms', Journal of Small Business and Enterprise Development performance in family firms', Journal of Small Business and Enterp
23(2), 379-407. https://doi.org/10.1108/JSBED-02-2015-0020

Lee, G., 2014, 'Seeking rigor in South African business research: Aspirational principles in contrast to a recent publication', South African Journal of Economics and Management Sciences 17(4), 501-514. https://doi.org/10.4102/sajems. v17i4.935

Lodh, S., Nandy, M. \& Chen, J., 2014, 'Innovation and family ownership: Empirical evidence from India', Corporate Governance: An International Review 22(1), 4-23. https://doi.org/10.1111/corg.12034

Lopez-Fernandez, M., Serrano-Bedia, A.M. \& Gómez-López, R., 2015, 'Determinants of innovation decision in small and medium-sized family enterprises', Journal of Small Business and Enterprise Development 23(2), 408-427. https://doi. org/10.1108/JSBED-02-2015-0028

Lotz, H.M. \& Van der Merwe, S.P., 2014, 'An assessment of selected organisationalbased factors on the perceived success of agrienterprises: A corporate entrepreneurship perspective', Southern African Business Review 17(3), 187-217.

Matchaba-Hove, M.T.M., 2013, 'The entrepreneurial orientation of small businesses in the Eastern Cape', Unpublished Master's dissertation, Nelson Mandela Metropolitan University. 
Matzler, K., Veider, V., Hautz, J. \& Stadler, C., 2015, 'The impact of family ownership, management, and governance on innovation', Journal of Product Innovation Management 32(3), 319-333. https://doi.org/10.1111/jpim.12202

Miroshnychenko, I., De Massis, A., Miller, D. \& Barontini, R., 2021, 'Family business growth around the world', Entrepreneurship Theory and Practice 45(4), 682-708.

Mitchell, M.L. \& Jolley, J.M., 2010, Research design explained, 7th edn., Cengage Learning, Belmont, CA.

Mohammed, S., Bint, N., Talib, A., Hayat, U. \& Kohar, A., 2020, 'Small and medium enterprises in the emerging economies: Does entrepreneurial orientation matter?', International Journal of Psychosocial Rehabilitation 24(5), 1065-1074. https://doi.org/10.37200/IJPR/V24I5/PR201781

Moses, C., Sithole, M.M., Blankley, W., Labadarios, D., Makelane, H. \& Nkobole, N., 2011, 'The state of innovation in South Africa: Findings from the South African National Innovation Survey', South African Journal of Science 108(7), 15-20. https://doi.org/10.4102/sajs.v108i7/8.1320

Murphy, L. \& Lambrechts, F., 2015, 'Investigating the actual career decision of the next generation: The impact of family Business involvement', Journal of Family Business Strategy 6(1), 33-44. https://doi.org/10.1016/j.jfbs.2014.10.003

Nagy, A. \& Băbăiță, C.,2016, 'Factors influencing the orientation towards innovation in the hospitality industry - The case of Romanian hotels', Annals of Faculty of Economics, University of Oradea 1(1), 584-595.

Nasution, H., Mavondo, F., Jekanyika, M. \& Oly, N., 2011, 'Entrepreneurship: Its relationship with market orientation and learning orientation and as antecedents to innovation and customer value', Industrial Marketing Management 40(1) 336-345. https://doi.org/10.1016/j.indmarman.2010.08.002

Nieto, M.J., Santamaria, L. \& Fernandez, Z., 2015, 'Understanding the innovation behavior of family firms', Journal of Small Business Management 53(2), 382-399. https://doi.org/10.1111/jsbm.12075

Oliveira, P. \& Roth, A.V., 2012, 'Service orientation: The derivation of underlying constructs and measures', International Journal of Operations and Production Management 32(2), 156-190. https://doi.org/10.1108/01443571211208614

Paula, F.D.O. \& Silva, J.F.D., 2018, 'Balancing internal and external R\&D strategies to improve innovation and financial performance', Brazilian Administration Review 15(2), 1-26. https://doi.org/10.1590/1807-7692bar2018170129

Price, D.P., Stoica, M. \& Boncella, R.J., 2013, 'The relationship between innovation, knowledge and performance in family and non-family firms: An analysis of SMEs', Journal of Innovation and Entrepreneurship 2(14), 1-20. https://doi. org/10.1186/2192-5372-2-14

Rahman, M.P. \& Kavida, V., 2019, 'Factors determining the innovation types of manufacturing SMEs in India', Asia-Pacific Journal of Management Research and Innovation 14(3), 94-110. https://doi.org/10.1177/2319510X18817647
Riaz, H., Akhtar, C. \& Aslam, R., 2018, 'Total rewards and employee performance: Investigating the mediating role of employee motivation in telecom sector', Pakistan Administrative Review 2(3), 342-356.

Riswanto, A., Rasto, R., Hendrayati, H., Saparudinc, M., Abidin, A. \& Primafira, A., 2020, 'The role of innovativeness-based market orientation on marketing performance of small and medium-sized enterprises in a developing country' Management Science Letters 10(1), 1947-1952. https://doi.org/10.5267/j. msl.2020.2.019

Röd, I., 2016, 'Disentangling the family firm's innovation process: A systematic review', Journal of Family Business Strategy 7(1), 185-201. https://doi.org/10.1016/j. jfbs.2016.08.004

Rogerson, C.M., 2018, 'Innovation-driven local economic development: In search of best practice implementation for South Africa', Euro Economica 37(1), 21-34.

Smith, M., 2008, 'Differences between family and non-family SMEs: A comparative study of Australia and Belgium', Journal of Management \& Organization 14(1), 40-58. https://doi.org/10.1017/S1833367200003461

Soininen, J., Martikainen, M., Pumaonen, K. \& Kylaheiko, K., 2012, 'Entrepreneurial orientation: Growth and profitability of Finnish small and medium-sized enterprises', International Journal of Production Economics 140(2), 614-621. https://doi.org/10.1016/j.ijpe.2011.05.029

Talib, S.A. \& Shafie, M.F., 2016, 'The influence of entrepreneurial orientation on restaurant business performance', in S.A. Jamal, S.M. Radzi, N.C.T. Sumarjan, N.S. Chik \& M.F.B. Bakhtiar (eds.), Hospitality and tourism 2015: Proceedings of HTC 2015, pp. 63-66, Taylor and Francis Group, London.

Uzkurt, C., Kumar, R., Kimzan, H.S. \& Eminoğlu, G., 2013, 'Role of innovation in the relationship between organizational culture and firm performance', European Journal of Innovation Management 16(1), 92-117. https://doi.org/ 10.1108/14601061311292878

Vieites, A.G. \& Calvo, J.L., 2011, 'A study on the factors that influence innovation activities of Spanish big firms', Technology and Investment 2(1), 8-19. https://doi. org/10.4236/ti.2011.21002

Voigt, K.I., Baccarella, C. \& Wassmus, A., 2011, 'The effects of customer orientation on the product performance of technological innovations: A comparison between SMEs and large companies', 31 July-04 August 2011 in 2011 Proceedings of PICME '11: Technology Management in the Energy-smart World (PICMET), IEEE, Portland.

Werner, A., Schroder, C. \& Chlosta, S., 2018, 'Driving forces of innovation in family and non-family SMEs', Small Business Economics 50(1), 201-218. https://doi org/10.1007/s11187-017-9884-4

White, M., Maru, L. \& Boit, R.J., 2015, 'Financial resource as drivers of performance in small and micro enterprises in service retail sector: A case of Eldoret Municipality, Uasin Gishu Country, Kenya', Global Journal of Human-Social Science: Economics 15(4), 4-15 


\section{Appendix 1}

TABLE 1-A1: Items used in the questionnaire.

Pariable

Innovation output
The financial well-being of our enterprise is secure.

Our enterprise has experienced growth in profits over the past 2 years.

I regard our enterprise as being financially successful.

Our enterprise is profitable.

Our enterprise has been able to achieve its financial goals.

Our enterprise has experienced growth in sales over the past 2 years.

Our enterprise provides customers/clients with products/services that offer unique benefits that are superior to those of our competitors.

Our enterprise has brought several products and/or services to the market in recent years.

In our enterprise, we improve on the products/services offered to our local market.

In our enterprise, we regularly make unique changes to the appearance, packaging, shape and volume of our offerings without changing their basic technical and functional features.

In our enterprise, we are consistently improving our enterprise processes.

In our enterprise, we regularly reduce wastage and minimise the costs of our products/services through process enhancements.

In our enterprise, there is a long-term commitment to invest in new operating technologies, equipment, machinery, R\&D and continuous improvement.

In our enterprise, we routinely renew the in-enterprise management information system and information-sharing practices.

In our enterprise, we routinely renew the organisational structure to facilitate communication and coordination between different functional areas in the enterprise.

In our enterprise, we frequently renew the routines, procedures and processes employed to execute enterprise activities.

In our enterprise, we consistently come up with new and creative ways to market our products/services to our current and potential customers/clients.

Our enterprise focusses on exploring and providing unique customer and after-sales services to our customers.

Our enterprise regularly renews product/service pricing and promotion techniques employed for the pricing of current and/or new products.

Financial resources In our enterprise, we generate sufficient financial resources to fund changes in our enterprise's products, services or processes.

In our enterprise, we make use of external funding (such as bank loans or government funding) to fund changes in our enterprise's products, services or processes.

In our enterprise, we make use of funding from friends to fund changes in our enterprise's products, services or processes.

In our enterprise, we routinely allocate financial resources to the development of new products/services or enterprise practices.

In our enterprise, we make use of family capital to fund changes in our enterprise's products, services or processes.

Human resources and leadership

In our enterprise, the owners/managers and employees have sufficient knowledge, experience and qualifications to identify and implement new enterprise opportunities successfully.

Our enterprise is able to recruit top-quality employees with relevant qualifications, skills and experience.

Our enterprise consistently promotes and/or provides comprehensive quality education and training for our employees.

In our enterprise, employees are dedicated and have a positive attitude towards innovation activities.

In our enterprise, employees have experience in identifying and implementing new enterprise opportunities that are related to the products and services in our industry.

Information and knowledge In our enterprise, we consistently make use of social media to communicate and gather information about new opportunities in our industry and/or identify current and potential competitors and customers.

In our enterprise, we consistently make use of smartphones to communicate and gather information about new opportunities in our industry and/or identify current and potential competitors and customers.

In our enterprise, we consistently make use of email and instant messaging to communicate and gather information about new opportunities in our industry and/or identify current and potential competitors and customers.

In our enterprise, we spend a lot of time and effort networking with people outside the enterprise to obtain relevant information (e.g. suppliers, customers, government, tertiary institutions).

In our enterprise, we have the ability to acquire relevant information from reliable sources which are inside the enterprise.

In our enterprise, we have the ability to conduct our own research to acquire relevant industry and market-related information.

Entrepreneurial orientation
Our enterprise has the ability and eagerness to identify new enterprise opportunities.

Our enterprise has the capacity and willingness to engage in innovative activities.

With regard to the competition, our enterprise usually acts proactively to initiate actions, to which our competitors respond

Our enterprise commits a large portion of its resources towards risky ventures to grow.

Our enterprise invests heavily in entrepreneurial products or market initiatives of which the ultimate success is uncertain. 
TABLE 1-A1 (continues...): Items used in the questionnaire.

\section{Variable \\ Market orientation}

Organisational culture

\section{Items}

In our enterprise, we encourage customer feedback, comments and complaints.

In our enterprise, it is quick to detect changes in repeat customer preferences.

In our enterprise, we monitor customer satisfaction.

In our enterprise, we are committed to our customers.

In our enterprise, we are able to identify current and potential competitors.

In our enterprise, we are able to identify and assess competitors' strengths, weaknesses and strategies.

Our enterprise responds swiftly to competitor strategies and actions that threaten the enterprise.

In our enterprise, we encourage employees to think and behave in original and novel ways.

In our enterprise, employees are supported and encouraged to take calculated risks with new ideas.

In our enterprise, employees are allowed to try and solve the same problem in different and creative ways.

In our enterprise, we actively encourage our employees to identify new enterprise opportunities or change existing work processes.

The owners/managers of our enterprise support research and technological development activities.

In our enterprise, family members exert control of the enterprise's strategic decisions.

In our enterprise, non-family employees are treated as part of the family. 